\title{
PEMBELAJARAN MENULIS TEKS ARGUMENTASI BERBASIS KEARIFAN LOKAL YANG BERORIENTASI PENDIDIKAN KARAKTER PADA SISWA KELAS VIII
}

\author{
Oleh \\ Bernadetta Sormin \\ Pendidikan Bahasa dan Sastra Indonesia \\ Pascasarjana Universitas Negeri Medan \\ bernadetta.sormin@gmail.com
}

\begin{abstract}
ABSTRAK
Bahasa dipelajari dalam bentuk empat keterampilan dasar, yaitu menyimak, berbicara, membaca, dan menulis. Kemampuan membaca diperlukan khususnya oleh siswa untuk kepentingan mencari literatur yang terkait dengan pelajaran yang mereka pelajari. Begitu pula, kebutuhan akan kemampuan menulis juga sangat dibutuhkan dalam dunia pendidikan. Banyak guru dan siswa yang beranggapan bahwa menulis itu merupakan keterampilan berbahasa yang paling sulit. karena banyak unsur yang terlibat di dalamnya, seperti unsur kebahasaan, isi (pesan yang akan disampaikan) dan ragam tulisan yang akan dibuat. kemampuan menulis teks argumentasi pada siswa dengan menggunakan model pembelajaran menulis teks argumentasi berbasis kearifan lokal yang berorientasi pendidikan karakter dapat diterapkan. Kearifan budaya lokal selain memiliki nilai-nilai yang positif ternyata dapat membantu untuk meningkatkan kompetensi menulis catatan harian dan mengubah karakter siswa yang negatif menjadi positif. Kompetensi menulis siswa meningkat disebabkan sumber inspirasi yang berasal dari kearifan budaya lokal lebih mudah dipahami dan telah dikenali oleh siswa sebelumnya.
\end{abstract}

Kata kunci: teks argumentasi, kearifan lokal, pendidikan karakter.

\section{A. PENDAHULUAN}

Bahasa dipelajari dalam bentuk empat keterampilan dasar, yaitu menyimak, berbicara, membaca, dan menulis. Kemampuan membaca diperlukan khususnya oleh siswa untuk kepentingan mencari literatur yang terkait dengan pelajaran yang mereka pelajari. Begitu pula, kebutuhan akan kemampuan menulis juga sangat dibutuhkan dalam dunia pendidikan. Banyak guru dan siswa yang beranggapan bahwa menulis itu merupakan keterampilan berbahasa yang paling sulit. karena banyak unsur yang terlibat di dalamnya, seperti unsur kebahasaan, isi (pesan yang akan disampaikan) dan ragam tulisan yang akan dibuat. Sebagai akibat dari anggapan ini, pembelajaran materi menulis sering dihindari untuk diajarkan dengan berbagai alasan. Kemampuan menulis sangat penting untuk dikuasai peserta didik karena pada hakikatnya menulis merupakan sarana untuk menuangkan gagasan, pendapat, perasaan, keinginan, serta informasi ke dalam tulisan dan kemudian menginformasikannya kepada orang lain. 
Kemampuan menulis sangat penting untuk dikuasai peserta didik karena pada hakikatnya menulis merupakan sarana untuk menuangkan gagasan, pendapat, perasaan, keinginan, serta informasi ke dalam tulisan dan kemudian menginformasikannya kepada orang lain. Keterampilan ini pun merupakan salah satu kegiatan yang kompleks karena penulis tidak hanya dituntut untuk dapat menyusun dan mengorganisasikan isi tulisannya tetapi harus mampu pula menuangkan gagasannya dalam bentuk bahasa tulis yang mudah dipahami pembaca. Selain itu, penulis harus mengikuti konvensi penulisan lainnya. Keterampilan menulis memiliki banyak manfaat, di antaranya dapat meningkatkan kecerdasan, dapat mengembangkan daya inisiatif dan kreativitas, menumbuhkan keberanian, serta dapat menjadi pendorong kemauan dan kemampuan mengumpulkan informasi (Suparno dan Yunus: 1.4).

Menurut Pennebeker menulis memiliki manfaat yang sangat besar, yaitu (1) menjernihkan pikiran, (2) mengatasi trauma; (3) membantu mendapatkan dan mengingat informasi baru, (4) membantu memecahkan masalah, (5) membantu kita ketika kita terpaksa harus menulis. Para pakar berpendapat bahwa kegiatan menulis itu sangat mudah asal sering dilatih secara intensif dan berkesinambungan. Salah satu kiat pelatihan menulis yang mudah dan jitu adalah menulis catatan harian secara intens. Sebagaimana Mirriam dan Goldberg (2006: 62) mengatakan bahwa menulis catatan harian secara teratur merupakan cara bagus untuk memperoleh kendali lebih besar atas penggunaan bahasa dan untuk mengasah keahlian seseorang sebagai penulis.

Alasan menulis teks argumentasi menjadi alternatif untuk meningkatkan kemampuan menulis siswa SMP didasarkan pada pendapat para pakar, yang mengatakan bahwa melalui kegiatan menulis teks argumentasi ini seorang calon penulis dapat memiliki kebebasan untuk mengekspresikan gagasan atau idenya. Selain keintensifan yang diperlukan untuk kegiatan pelatihan menulis, seorang calon penulis dapat dibantu untuk mendapatkan inspirasi sebanyakbanyaknya. Inspirasi yang paling dekat dengan kehidupan siswa SMP dan dialami langsung oleh mereka adalah budaya. Di dalam perwujudan budaya ini terkandung nilai-nilai kebaikan yang dapat menjadi inspirasi dan teladan siswa.

Nilai-nilai yang positif tersebut adalah kearifan budaya lokal. Kearifan budaya lokal dapat diinternalisasikan dalam pendidikan karena dia memiliki banyak kelebihan. Kelebihan tersebut antara lain sebagai berikut: (1) Kearifan budaya lokal dapat menjadi sarana pembelajaran bagi setiap manusia untuk menjadi orang yang cerdas, pandai, dan bijaksana, (2) Kearifan budaya lokal memiliki nilai-nilai positif untuk ditransformasikan kepada peserta didik guna membentuk kepribadian positif. Sebagaimana Sayuti (2009) mengemukakan bahwa budaya dan potensi lokal itu meniscayakan fungsi yang strategis bagi pembentukan karakter dan identitas. Atas dasar hal tersebut, selayaknyalah kearifan budaya lokal diintegrasikan dalam pembelajaran menulis catatan harian karena selain memberi inspirasi bahan tulisan, juga berfungsi untuk membentuk karakter dan identitas siswa itu sendiri.

Berdasarkan pada uraian tersebut, perlu dilakukan pengujian untuk membuktikan bahwa model pembelajaran menulis teks argumentasi berbasis kearifan budaya lokal yang berorientasi pendidikan karakter lebih efektif untuk meningkatkan kemampuan menulis siswa dan dapat memberikan banyak inspirasi bahan tulisan dan perubahan karakter siswa SMP. 


\section{B. MODEL PEMBELAJARAN}

Model pembelajaran merupakan kerangka konseptual atau pola suatu pembelajaran. Kerangka konseptual atau pola tersebut dirancang untuk melaksanakan suatu pembelajaran yang di dalamnya tercakup tujuan-tujuan pengajaran, tahap-tahap dalam kegiatan pembelajaran, lingkungan pembelajaran, dan pengelolaan kelas. Semua unsur tersebut disusun secara sistematis untuk mengorganisasikan pengalaman belajar dalam rangka mencapai tujuan pembelajaran. Rancangan ini menjadi pedoman guru dalam mempersiapkan dan melaksanakan kegiatan belajar mengajar. Model ini dibuat dengan tujuan untuk membantu guru dalam mengaplikasikan kurikulum, mengembangkan materi ajar, dan melaksanakan pembelajaran di kelas.

Menulis teks argumentasi merupakan salah satu bentuk tulisan yang memberikan ide tentang suatu peristiwa. Kebiasaan menulis teks akan membantu meningkatkan kemampuan menulis. Demikian pula Semi (2007: 10) mengatakan bahwa kebiasaan menulis teks merupakan kebiasaan yang sangat baik dan sangat menunjang di dalam meningkatkan keterampilan menulis.

Kearifan Budaya Lokal Secara umum local wisdom (kearifan setempat) dapat dipahami sebagai gagasan-gagasan setempat (local) yang bersifat bijaksana, penuh kearifan, bernilai baik, yang tertanam dan diikuti oleh anggota masyarakatnya. Sedangkan, yang dimaksud kearifan budaya adalah seluruh usaha dan hasil usaha manusia atau masyarakat yang dilakukan dan ditujukan untuk memberikan makna manusiawi dan membuat tata kehidupan manusiawi pula. Dalam rangka memenuhi kebutuhan hidupnya, usaha dan hasil budaya manusia diarahkan untuk meningkatkan harkat dan nilai-nilai luhur kemanusiaan. Pendidikan Karakter Pendidikan karakter merupakan kebutuhan yang vital untuk menghadapi tantangan regional dan global. Adanya tantangan regional dan global ini menuntut agar generasi muda (peserta didik) tidak hanya sekadar memiliki kemampuan kognitif saja, tapi juga aspek afektif dan moralitas. Untuk itu, pendidikan karakter sangat diperlukan untuk mencapai manusia yang memiliki integritas nilai-nilai moral yang menjadikan seseorang memiliki kepribadian hormat pada sesama, jujur, dan peduli terhadap lingkungan.

\section{TEKS ARGUMENTASI}

Keterampilan menulis merupakan salah satu bentuk keterampilan berbahasa yang sangat penting bagi peserta didik di samping keterampilan menyimak, berbicara, dan membaca baik selama pendidikan maupun dalam kehidupannya nanti di masyarakat. Keberhasilan siswa dalam mengikuti kegiatan belajar-mengajar di sekolah banyak ditentukan kemampuannya dalam menulis. Oleh karena itu, pembelajaran menulis mempunyai kedudukan yang sangat strategis dalam pendidikan dan pengajaran. Menulis merupakan suatu keterampilan berbahasa yang produktif dan ekspresif. Dengan menulis seseorang akan lebih mengenali potensi dan kemampuan dirinya dalam berpikir, bernalar, berpengetahuan, mengembangkan gagasan dan menyerap berbagai informasi. Di samping itu, bagi yang rajin menulis akan terlatih dalam memperluas gagasan secara sistematis dan logis. Argumentasi adalah salah satu bentuk penulisan paragraf atau pendapat dalam sebuah kalimat yang menerangkan sebuah penjelasan, alasan, pembuktian, pro, dan kontra yang disertai alasanalasan obyektif, fakta aktual, nyata, valid, dan kuat terhadap paragrapnya yang bertujuan untuk meyakini si pembaca agar merasa simpati, berpendapat yang sama dengan si pembaca, 
dan terpengaruhi. Komposisi penulisan kalimat argumentasi tidak ditulis sembarang begitu saja. Secara umum ada 3 urutan struktur teks dalam menulis atau mengungkapkan kalimat argumentasi. Urutan inipun tidak boleh dibolak-balik atau diacak karena apabila hal tersebut dilakukan, maka akan membuat isi teks menjadi susah dipahami dan tidak mengalir. Tentu saja keadaan tersebut juga membingungkan dan menimbulkan salah pengertian pada para pembaca. Pendahuluan, bagian pendahuluan berisi latar belakang masalah atau pengenalan masalah. Kalimat yang digunakanpun cukup menarik dengan menggunakan gaya bahasa sedemikian rupa sehingga akan menarik perhatian si pembaca. Isi atau badan kalimat argumantasi, bagian ini berisi pendapat, ide, point of view, dan gagasan, yang disertai dengan fakta yang menguatkan sekaligus membuktikan gagasan tersebut benar adanya. Penutup yang terdiri dari kesimpulan akhir, berisi kesimpulan yang logis dan dapat diterima oleh nalar si pembaca.

\section{KEARIFAN LOKAL BUDAYA}

Secara umum local wisdom (kearifan setempat) dapat dipahami sebagai gagasangagasan setempat (local) yang bersifat bijaksana, penuh kearifan, bernilai baik, yang tertanam dan diikuti oleh anggota masyarakatnya. Sedangkan, yang dimaksud kearifan budaya adalah seluruh usaha dan hasil usaha manusia atau masyarakat yang dilakukan dan ditujukan untuk memberikan makna manusiawi dan membuat tata kehidupan manusiawi pula. Dalam rangka memenuhi kebutuhan hidupnya, usaha dan hasil budaya manusia diarahkan untuk meningkatkan harkat dan nilai-nilai luhur kemanusiaan.

\section{E. PENDIDIKAN KARAKTER}

Pendidikan karakter merupakan kebutuhan yang vital untuk menghadapi tantangan regional dan global. Adanya tantangan regional dan global ini menuntut agar generasi muda (peserta didik) tidak hanya sekadar memiliki kemampuan kognitif saja, tapi juga aspek afektif dan moralitas. Untuk itu, pendidikan karakter sangat diperlukan untuk mencapai manusia yang memiliki integritas nilai-nilai moral yang menjadikan seseorang memiliki kepribadian hormat pada sesama, jujur, dan peduli terhadap lingkungan.

\section{F. PENUTUP}

Berdasarkan hasil catatan di lapangan, dapat disimpulkan bahwa kemampuan menulis teks argumentasi pada siswa dengan menggunakan model pembelajaran menulis teks argumentasi berbasis kearifan lokal yang berorientasi pendidikan karakter dapat diterapkan. Kearifan budaya lokal selain memiliki nilai-nilai yang positif ternyata dapat membantu untuk meningkatkan kompetensi menulis catatan harian dan mengubah karakter siswa yang negatif menjadi positif. Kompetensi menulis siswa meningkat disebabkan sumber inspirasi yang berasal dari kearifan budaya lokal lebih mudah dipahami dan telah dikenali oleh siswa sebelumnya.

\section{DAFTAR RUJUKAN}

Aunurrahman. 2009. Belajar dan Pembelajaran, Bandung: Alfabeta. 
Beetlestone, Florence.1998. Creative Children: Imaginative Teaching, Philadelphia:

Open University Press.

Beetlestone, Florence. 2011. Creative Learning: Strategi Pembelajaran untuk Melesatkan

Kreatifitas Siswa. Terjemahan Narulita Yusron. Bandung: Nusa media

De Porter, Bobbi, and Mike Hernacki. 2010. Quantum Learning: Membiasakan Belajar Nyaman dan Menyenangkan.Terrjemahan Alwiyah Abdurrahman. Bandung: Kaifa PT Mizan Pustaka.

Koesoema, Doni A.2007. Pendidikan Karakter: Strategi Mendidik Anak di zaman

Global. Jakarta: PT Grasindo.

Komaidi, Didik. 2008. Aku Bisa Menulis. Yogyakarta: Sabda.

Munir, Abdullah. 2010. Pendidikan Karakter: Membangun Karakter Anak Sejak dari

Rumah. Yogyakarta: Pedagogia. 